\title{
27. SUMMARY AND CONCLUSIONS
}

\author{
W. E. Benson, Earth Sciences Section, National Science Foundation \\ R. D. Gerard, ${ }^{1}$ Lamont-Doherty Geological Observatory, Columbia University \\ and \\ W. W. Hay, Institute of Marine Sciences, Univ. of Miami and Dept. of Geol., Univ. of Illinois
}

\section{INTRODUCTION}

In contrast to Legs 2 and 3 , the scientific objectives for most of the sites of Leg 4 were not closely interrelated, but were selected to enhance knowledge of several subjects, such as the nature of basins adjacent to continental margins, sea floor spreading, nature of transverse fractures of the Mid-Atlantic Ridge, geology of island arcs and trenches, and the geologic history of the Caribbean. It is therefore neither practical nor desirable to attempt a regional synthesis for the whole cruise, as this area will be more extensively investigated on the forthcoming Legs 14 and 15.

In the following section the conclusions resulting from knowledge of the geology of each site will be presented first, followed by general discussion of several topics of particular interest developed on Leg 4, particularly the problems of sedimentation rates, the history of calcium carbonate compensation in the Atlantic, and the nature and relations of subbottom reflecting horizons.

\section{THE BRAZIL BASIN}

\section{Sites 23 and 24}

The objectives at Site 23 were to sample and determine the nature of the intermediate reflector (possibly analogous to Horizon A in the North Atlantic) and basement in this part of the Brazil Basin. Sampling of "basement" was not achieved, although drilling penetrated basalt. Coring of the sediments revealed features of the geological history extending back to Lower Miocene for this area.

The upper $100 \pm$ meters of sediment at this site are thought to be essentially "red clays." Core 4 was taken at the predicted depth of Horizon "A", and represents a different kind of sediment, greenish silty clays with interbedded sand layers bearing considerable resemblance to alpine "flysch". Horizon "A" may well be one of the turbidite sands.

The surficial sediment contains some calcareous plankton fossils and is green-gray in color but rapidly grades downward into barren "red clays". The thickness of red clay in Hole 23 can be assumed to be about 100 meters (it must be more than 70 meters and less than

\footnotetext{
${ }^{1}$ Lamont-Doherty Contribution No. 1557.
}

110 meters), as it would seem likely that the entire interval above Horizon "A" is "red clay". The occurrence of nannoplankton and planktonic foraminifera is sporadic and uneven. Nannoplankton are present throughout the uppermost 10 meters of sediment, but the assemblages are very poor at most levels, and planktonic foraminiferal assemblages are very sparse except for the planktonic foraminiferal sand at a depth of about 3 meters. Nannoplankton and planktonic foraminifera are virtually absent from deeper sediments. Fortunately, a small sample taken from the drill bit plug prior to taking Core 2 contained an adequate nannoplankton sample to permit dating of the material as belonging to the Discoaster hamatus Zone (Globorotalia menardii Zone). From this a sedimentation rate for the upper 50 meters of "red clay" can be estimated to be about $5 \mathrm{~mm} / 10^{3}$ years.

The sedimentation rate calculated for this Upper Middle Miocene to Lower Pleistocene "red clay" sequence is higher than that suggested by Holmes $(1964 ; 0.7$ to $2 \mathrm{~mm} / 10^{3}$ years) by a factor of more than 2 . The introduction of layers of material from shallower waters (above the compensation depth) is suggested by the planktonic foraminiferal sand in Section 2 of Core 1, and if these are distributed throughout the sequence, they may serve to account for the high rate of sedimentation.

The paucity of nannoplankton and planktonic foraminifera indicates that this site is at present in the lower reaches of the lysocline for calcium carbonate, and was well below the compensation depth during the Middle Miocene; the planktonic foraminiferal sand may be considered to be derived from a higher source, above the compensation depth, or may be considered to represent a lowering of the compensation level to permit accumulation of calcareous fossils. The sandy character of the deposit favors the derivation hypothesis; mode of transport would presumably be a turbidity current, although it is important to note that the planktonic-foraminiferal sand contains no quartz or other terrigenous material.

All that is known with certainty concerning the thickness of the greenish silty clay sand sequence from Site 23 is that it must exceed 30 meters. The clayey layers are virtually devoid of calcareous fossils; the 
sandy layers contain abundant nannoplankton and planktonic foraminifers. The planktonic foraminiferal assemblages all belong to the Globorotalia kugleri Zone. The sand layers are partially cemented but lack cohesion, and seem to have been recovered only where trapped on top of or sandwiched between the stickier, more cohesive argillaceous layers. The sand contains much quartz, most of the fragments are angular.

Sedimentation rate for the short interval cored is difficult to estimate, but if it is assumed that the 30 meters cored represent all of the Globorotalia kugleri Zone, and that the duration of the zone was 2 million years (a very high estimate), a minimal sedimentation rate of $15 \mathrm{~mm} / 10^{3}$ years is obtained. This is approximately an order of magnitude higher than that suggested for "red clay" by Holmes (1965), and about three times that for Globigerina ooze encountered on earlier legs.

Once again, absence of nannoplankton and planktonic foraminifera indicates that these sediments were deposited below the compensation depth. The major contact encountered in Hole 23 is that between the "red clay" and the green turbidites. Both sediments were deposited at or below the compensation depth; the green turbidites somewhat more deeply below the compensation level than the upper part of the "red clay". The age of the contact must be Lower or Middle Miocene.

The primary differences between the two materials are: (a) color, and (b) quantity of coarse detritus. Significance of the color difference will not be discussed here. The quantity of detritus is important; the green turbidites were derived rapidly from a source of primary-not recycled-quartz, and must reflect uplift, erosion, and subsequent transportation to this site of deposition. As possible sources the obvious sites might be: (1) the Natal, Sao Francisco region; (2) the Amazon region; and, (3) an adjacent oceanic site. In the case of (1) and (3) cessation of uplift and erosion would produce the change from turbidites to clay. In the case of (2) an opposing current would produce the change (note that present Amazon sediments are drifted north). It would seem possible that the contact might represent the time of origin of the Antarctic Bottom Current.

At a depth of about 185 meters below the sea floor, two meters of basalt were penetrated with a recovery of only 0.5 meter. The rock is heavily altered and much of the texture has been destroyed, but it appears to have been diabasic or porphyritic. The small thickness of the bed together with the comparatively coarse texture and the lack of glass, which might be the result of alteration, suggest that this rock may be part of a sill rather than a flow. Alternatively, it may be a rubble derived from one of the known nearby submarine peaks. Several of the larger basalt fragments exhibit steeply dipping banding which might be the result of tectonic disturbance. Since softer materials were encountered below the basalt, it is not considered to represent "basement" rock.

Because Site 24 was only about 10 miles from Site 23, and was a substitute for this site, the upper part of Holes 24 and 24A were not cored. The basalt that was cored at about 185 meters in Hole 23 was not encountered in either Hole 24 or $24 \mathrm{~A}$.

Two sequences were cored at Site 24 from 198 to 235 meters (Hole 24), and from 503 to 558 meters (Hole 24A). In general aspect, the sediments cored in both holes resemble geosynclinal "flysch", suggesting that flysch beds can be deposited in very deep as well as moderately deep water.

The upper sequence is of Early Miocene age (as at Site 23) and consists of greenish-gray and brownishgray compacted clay interbedded with relatively thin beds of medium to fine-grained quartz sand turbidites, strongly resembling those found in Hole 23 . The clays are glauconitic, contain streaks and pellets of manganese oxide, and have minor amounts of terrigenous detritals.

At Site 24, the 40 meters of sediment assignable to the Globorotalia kugleri Zone are probably somewhat older than the 30 meters of the same zone cored at Site 23 . Assuming a length of 2 million years for the zonewhich is a very high estimate)-and a total thickness not less than 70 meters, a sedimentation rate of at least $35 \mathrm{~mm} / 10^{3}$ years is obtained. This is a figure seven times that for Globigerina ooze at sites on Legs 1,2 and 3.

The thicker or the more indurated of these sand beds are probably the source of the so-called Horizon "A" in this area. These beds are probably discontinuous, which would account for the "windows" in " $A$ " that were reported by the $R / V$ Vema.

The top of the lower cored sequence of Late Cretaceous age consists of greenish-gray and brownish-gray compacted mudstone that is locally indurated and contains up to 20 per cent terrigenous detritals plus a radiolarian fauna.

As the flysch-like turbidites above the basalt contain no calcareous fossils, they were apparently deposited below the depth of carbonate compensation. The few calcareous plankton fossils in the coarser beds were probably brought into the area by turbidity currents. These sediments have an aggregate thickness of more than 350 meters at Hole 24A, and can be assumed to be widely distributed over at least the western part of the Brazil Basin. They must represent erosion of a land mass of considerable size in order to account for the volume of accumulated sediment. 
The hole bottomed in basalt. This has been assigned arbitrarily to the bottom 61 centimeters of the hole (557.78 to 558.39 meters) despite the fact that the "core" contained about 1.52 meters of underlying material. The underlying material was a very fluid dark brown mud with fragments of the mudstone greywacke; the authors interpret it as having been drawn into the core barrel after the core run had been completed.

It is a moot question whether this basalt is true "basement" or whether older sediment lies below. This flow and others are undoubtedly the source of the "basement reflections", but it is possible that flows at various stratigraphic horizons may be the reason that the "basement" has such an apparent irregular topography in the area.

\section{NORTH BRAZILIAN RIDGE}

\section{Site 25 (R. D. G.)}

In their discussion of the origin and development of the North Brazilian Ridge, Hayes and Ewing (1970) found it difficult to reconcile the undisturbed sediments on both sides of the Ridge with the evidence of Post Mid or Late Miocene subsidence of the Ridge indicated by the drilling results. The presence of a prominent flat-lying intermediate reflector abutting the oceanic side of the Ridge requires that the undisturbed surrounding beds predate this supposed subsidence. The extent of this intermediate reflecting horizon is plotted throughout a broad area of the southwestern Guiana Basin (Hayes and Ewing, 1970), and is described as a possible counterpart to Horizon A of Eocene age in the North Atlantic (Ewing et al., 1966; Ewing et al., 1969; Ewing et al., 1970).

As noted elsewhere in this volume, reflecting horizons at Sites 23, 24 and 27 that had been tentatively called " $A$ " were not Eocene and not chert. They were turbidite sands, Miocene to Pleistocene in age. The nature of the reflector east of the Brazilian Ridge, thereafter, is not known.

In order to reconcile the conflicting evidence, the following hypothesis related to the ocean spreading mechanism would appear to fit the observed features of the Ridge. The results of Leg 3 (Maxwell et al., 1970) convincingly demonstrate a spreading rate for the floor of the South Atlantic (at $30^{\circ} \mathrm{S}$ latitude) of $2 \mathrm{~cm} / \mathrm{yr}$, although Ball and Harrison (1970) suggest a smaller rate in the latitude of the Antilles. The minimum distance between the Mid-Atlantic Ridge and the North Brazilian Ridge is about $1000 \mathrm{~km}$. If one assumes that separation and rotation of the continents of Africa and South America has taken place about an axis centered in the North Atlantic (Bullard et al., 1965; Morgan, 1968; LePichon, 1968; Fox et al., 1969), the present distance of the two ridge axes along an arc across the complex equatorial fracture zone region is about 2000 kilometers. Using the $2 \mathrm{~cm} / \mathrm{yr}$ spreading rate, a period of about 100 million years is indicated since the North Brazilian Ridge (and the South American continent) separated from the spreading center. This estimate is in accord with the Leg 3 results (Maxwell et al., 1970) and with data from Site 24 to the southeast, where the oldest sediments were of Upper Cretaceous age. It is also in agreement with the findings of Fox et al. (1970), who report dredging shallow-water sandstone of Late Jurassic age near the base of the Demerara Plateau northwest of the Amazon delta. Paleomagnetic evidence (Valencio and Vilas, 1970) suggests that the fragmentation of the South American-African block and the formation of the South Atlantic began in Lower Jurassic times.

If it can be assumed that the basement rock below the $4.8 \mathrm{~km} / \mathrm{sec}$ material at the base of the Brazilian Ridge was at or near the ocean surface at the time of origin, and that it has subsequently separated from the spreading center at the above rate and subsided to its present depth of nearly 5 kilometers below the ocean surface during that time, a subsidence rate of $0.05 \mathrm{~mm} / \mathrm{yr}$ is indicated. If the first part of this 100 million year movement were accompanied by reef growth, it would be possible to build some 2.8 kilometers of reef material on top of the sinking basement foundation. This suggested sequence for the development of the North Brazilian Ridge leaves many outstanding questions. The nature of the $1.8 \mathrm{~km} / \mathrm{sec}$ sedimentary material immediately below the drilled section is not explained. The $4.8 \mathrm{~km} / \mathrm{sec}$ zone may not be reef material, but an igneous or metamorphic rock, as suggested by Hayes and Ewing partly on the basis of bottom photographs of basalt-like rock from the eastern flank of the ridge. If this proves to be the case, then it seems likely that the top of the $4.8 \mathrm{~km} / \mathrm{sec}$ layer was initially at the ocean surface and the $3.8 \mathrm{~km} / \mathrm{sec}$ represents a reef growth which kept pace with subsidence. The subsidence of the North Brazilian Ridge would then be half the above rate for the first 50 to 70 million years and thereafter at the rate given in the first case $(0.05$ $\mathrm{mm}$ /year). Most theories, however, suggest that the subsidence rate should be greater in the earlier stages of spreading.

One hopes that these and other important questions can be answered through a well-planned drilling and sampling program in the North Brazilian Ridge area in the future.

In spite of the many uncertainties, this proposed spreading and subsidence origin is in accord with concepts used to explain the stratigraphy on other legs of the Deep Sea Drilling Project.

The same argument has been made to explain the presence of calcareous sediments beneath red clays sampled on Leg 3 of the Deep Sea Drilling Project. Results 
from a series of cores across $30^{\circ}$ South latitude (Maxwell et al., 1970) in the South Atlantic show that Lower Tertiary carbonate sediments deposited on the spreading and subsiding flanks of the Mid-Atlantic Ridge were covered by "red clays" in Upper Eocene-Lower Oligocene time. This change presumably took place as the flank depth decreased some 3000 meters to a level below the carbonate compensation depth. This process of simultaneous subsidence and spreading is also proposed to explain the carbonate-"red" clay sequence sampled on Leg 6 of the Deep Sea Drilling Project in the eastern Pacific (Fischer et al., 1970).

\section{VEMA FRACTURE ZONE}

\section{Site 26}

The Vema Fracture Zone is a deep trench crossing and offsetting the Mid-Atlantic Ridge. It is open at its western end to the Demerara Abyssal Plain, which separates the Ridge province from the continental shelf of South America. Reflection profiles across the Vema Fracture Zone show a steep, deep walled trench, partly filled with sediments. If the irregular bottom reflector is truly "basement", this sedimentary fill is 914 to 1066 meters thick. The nature of the sediment in the Vema Fracture Zone has been an enigma to marine geologists for some time. Van Andel et al. (1967) noted that a sedimentary thickness of more than one kilometer at such a great distance from the continent must represent a very long interval. However, the hypothesis of sea-floor spreading would suggest a very young age for that part of the fracture zone near the axis of the Mid-Atlantic Ridge. Coring and drilling in Holes 26 and $26 \mathrm{~A}$ show that the top 610 meters of this fill were deposited since the late Middle Pleistocene, i.e. during the last 500,000 years. This sedimentation gives an average rate of 30 centimeters per 250 years, a remarkably high rate for any supposedly non-subsiding area. A second noteworthy feature is that the sediments in the fracture zone seem to have been derived from the South American continent, and have been transported across the Demerara Plain.

Two possibilities are suggested: (1) the Vema Fracture Zone is of Tertiary age, but did not receive much sedimentation until Pleistocene because the basin under the Demerara Plain is very deep and trapped all the earlier sediments. (2) The Vema Fracture did not originate until the Pleistocene, and since has been filled rapidly by material carried across the Demerara Plain. The latter interpretation seems more probable.

Transportation of the large volume of Pleistocene sediments across the Demerara Abyssal Plain poses an interesting geologic problem. The deposits closely resemble turbidites, and sometimes exhibit graded bedding. If the source of this material is indeed the Amazon cone we must assume that turbidity currents flowing across the flat floor of the Guiana Basin have deposited vast amounts of material including sand and heavy minerals in the Vema Fracture Zone more than 500 kilometers to the northeast.

\section{NORTH SIDE OF DEMERARA ABYSSAL PLAIN}

\section{Site 27}

Three reflecting horizons were noted in the profiler records taken by the $R / V$ Vema and by the Glomar Challenger at Site 27.(Figure 2). These were calculated to lie at depths of about 70, 235 and 490 meters, respectively. The beds responsible for the upper reflections are somewhat puzzling. The upper part of the section is remarkably uniform, consisting of clays to a depth of at least 400 meters. Two turbidite layers were noted between 65 and 75 meters depth, but these are not indurated and seem rather thin to be responsible for the very good reflection noted on the profiler records. These thin turbidites are the only beds that differ from the clay which forms the bulk of the section, and are at the proper depth for the uppermost reflecting horizon. If these two turbidites do indeed cause the reflection, doubt is raised about the usefulness of Horizon " $A$ " as a basis for correlation in this area. The age of the turbidites cannot be determined with precision, but is probably no older than Pliocene. The intermediate reflector is even more of a problem. Either two minor turbidite stringers between 235 and 245 meters are the source of the echo, or it must be assumed that a thicker bed (presumably a turbidite) was penetrated in the uncored interval just above.

The lower cores taken in Hole 27 (Cores 6 and 7) at 455 to 475 meters below the sea floor recovered sediment strikingly similar in both lithology and age to that comprising the lower part of the Oceanic Formation exposed on the slopes of Mount Hillaby, Barbados. On Barbados, hard, "ash-like" limestones with Radiolaria occur in the basal hundred meters of the Oceanic Formation (Senn, 1940). The Oceanic Formation rests with angular and erosional unconformity on the diverse rocks of the Scotlands Group (Senn, 1940, 1948) which have been determined to be of Paleocene and Early to Middle Eocene age (Cizancourt, 1948). The deepest reflecting horizon recorded at Site 27 may have been the hard, calcareous rock recovered by Core 7 , or might be an unconformity at a slightly greater depth.

The correlation of the radiolarian rich calcareous sediments in the deeper part of Hole 27 with the Oceanic Formation of Barbados is obvious. This is apparently the first time that a formation which crops out on land has been found and sampled in situ in the upper part of the oceanic crust. It also implies that the Oceanic Formation is a unit of considerable areal extent, exhibiting structural relief in excess of 5000 meters. If this is true, it raises the question of whether Barbados has been uplifted from the deep ocean floor, or whether 


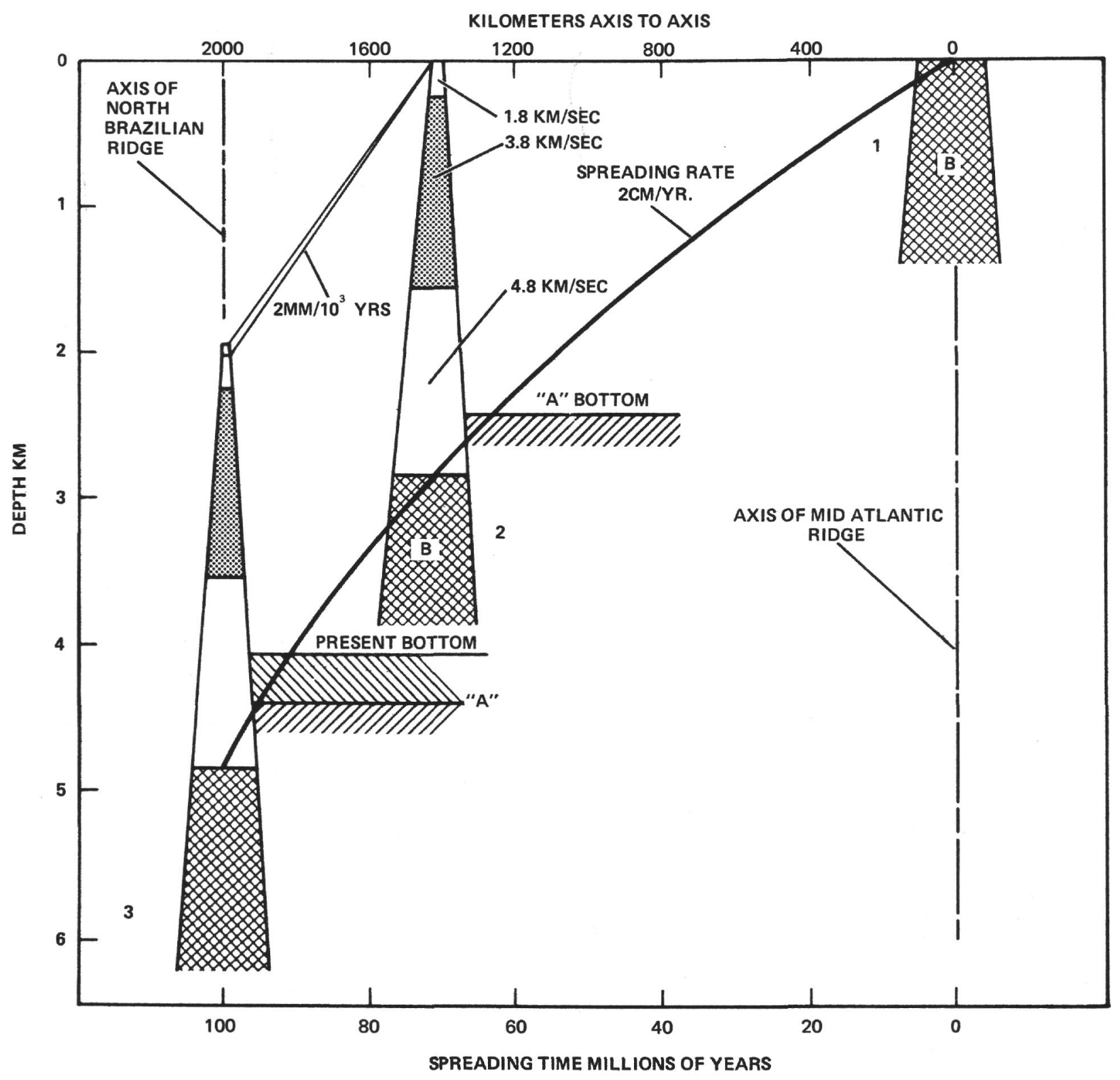

Figure 1. Schematic drawing of the development of the North Brazilian Ridge:

1) North Brazilian Ridge basement material at the time of origin in Late Mesozoic.

2) Position and nature of Ridge in Middle Tertiary time, indicating that reef growth has kept summit of Ridge near the ocean surface.

3) Present Ridge situation, showing 50 meters accumulation of pelagic ooze on crest since Mid-Tertiary subsidence.

Numbers beside Ridge component structures are seismic velocities from Hayes and Ewing (1970). 


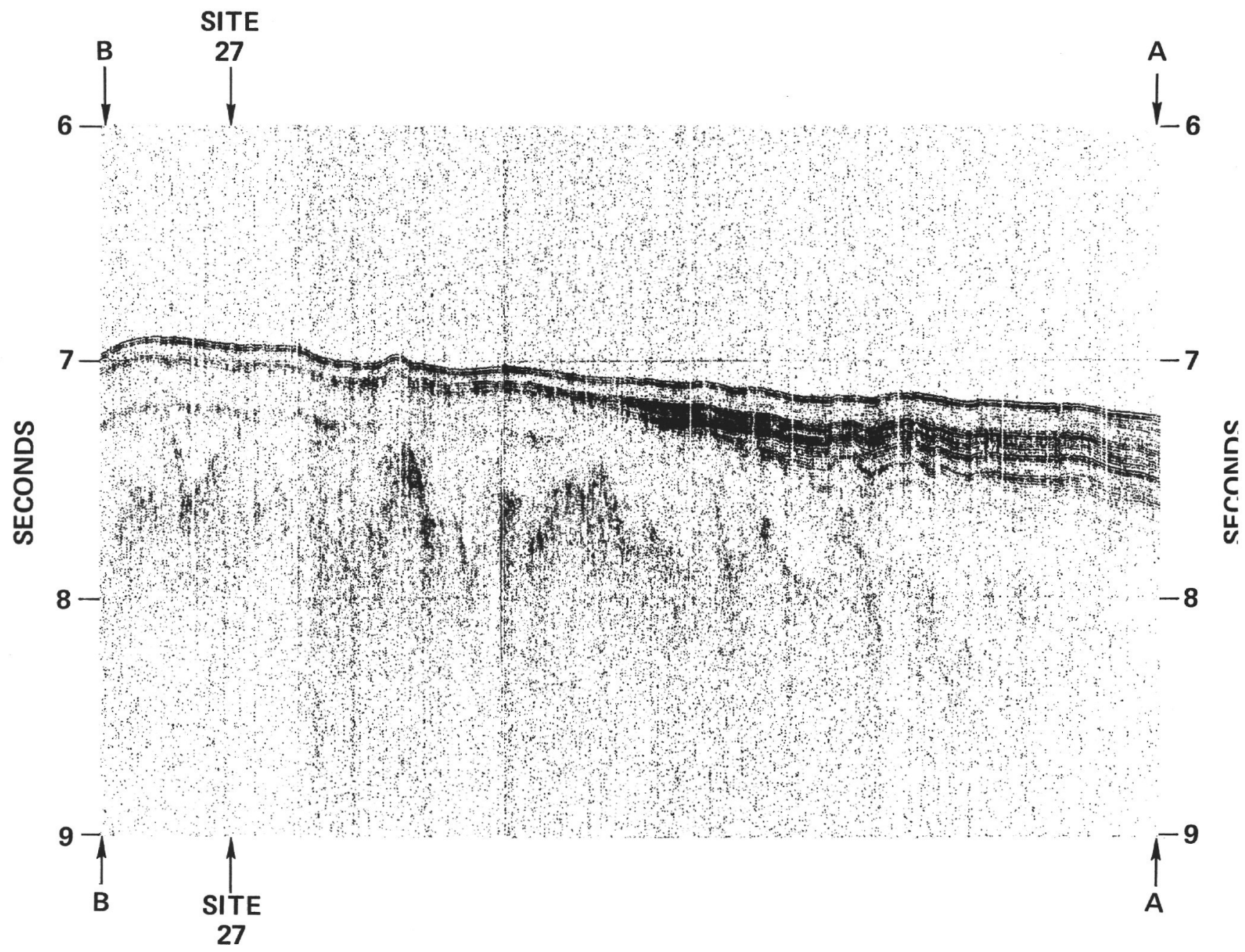

Figure 2. Seismic profiler record across Site 27, showing intermediate and basement reflectors. This transect $A-B$, from the R/V Vema site survey, is located on Figure 2, Chapter 6. 
the Barracuda Ridge area to the northeast has subsided. Beckmann (1953) concludes that the foraminiferal assemblage of the Oceanic Formation on Barbados indicates deposition in waters 1000 to 1500 meters deep, and that there are no cogent reasons for supposing a deep-sea origin of the radiolarian marls of Barbados. However, Saunders and Cordey (1968) consider the Oceanic Formation to be a deep water sediment, and T. W. Donnelly (personal communication) is of the opinion that Barbados has been uplifted from the deep ocean floor.

The cores from Hole 27 support the views of Saunders and Cordey and Donnelly. Below at least 370 meters, the clays at this site are slightly calcareous-to-noncalcareous, containing radiolarians, frequently calcareous nannoplankton, but no planktonic foraminifera in a condition suitable for identification. The few specimens of foraminifera, recovered consist of two or three juvenile chambers, the adult chambers having been dissolved. The sediments encountered in Hole 27 below 370 meters were deposited in the lower part of the zone of calcium carbonate compensation, at a depth below the level of solution of planktonic foraminifera but above the ultimate depth reached by calcareous nannoplankton fossils, that is, they are truly of deep water origin. The similarity to the Oceanic Formation of Barbados suggests that it too was deposited in the lower part of the region of calcium carbonate compensation in deep water.

The cores from higher parts of the Hole at Site 27 are entirely devoid of calcium carbonate fossils, and indicate deposition entirely below the calcium carbonate compensation zone.

The youngest deep sea deposits on Barbados are beds of Early Miocene age (Senn, 1948) which are unconformably overlain by Pleistocene coral formations. The drilling results from Site 27 indicate that the recognized post Miocene uplift of Barbados elevated the island (and presumably the Barbados Ridge) from the deep ocean floor.

\section{NORTH WALL OF PUERTO RICO TRENCH}

\section{Site 28}

The drilling objectives at Site 28 were to sample and date subbottom reflectors and to relate them to presumed comparable features in the North American Basin, and to sample the deepest portion of the sedimentary section suspected to contain carbonate rocks of Mesozoic age. Only the first of these objectives was partially fulfilled.

Another objective for drilling at Site 28 was to determine whether subsidence had taken place since the Cretaceous, as Cretaceous calcareous plankton were known from this area which currently lies below the calcium carbonate compensation level. No new evidence was gained by the borehole, but the problem of calcium carbonate compensation solution levels in the past and subsidence of the bottom had been largely answered by evidence from other sites drilled (see section on Calcium Carbonate Compensation in this chapter). As far as is known at present, almost all of the Atlantic sea floor was above the calcium carbonate compensation level and was an area of accumulation of calcareous pelagic oozes during the Late Cretaceous.

An upper acoustically transparent zone of 0.15 second reflection time, corresponding to the upper 175 meters, apparently includes beds from Recent to Late or Middle Eocene age. Middle Eocene sediments below 175 meters correlate with a semi-transparent zone to which Hersey (1966) ascribes an acoustical velocity of $4.2 \mathrm{~km} /$ sec. Although core recovery was exceedingly poor below 175 meters depth, indirect evidence from the drilling operation indicated alternating hard and softer materials. Damage to the diamond bit, believed to have occurred at this depth, suggests that the interbedded hard material was chert-like, thus indicating a tentative correlation with the cherts of Middle Eocene age forming Horizon A in the North Atlantic.

\section{VENEZUELAN BASIN}

\section{Site 29}

The Caribbean basins, lying between the tectonically active areas of the Antillean Island Arc and Central America, have long been recognized as anomalous oceanic areas. Classical continental geologists, including Willis (1932), Schuchert (1935), Eardley (1951), and others have considered the Caribbean to be a subsiding block of continental crust. Marine geologists, such as Ewing et al. (1957) and Officer et al. (1959) have suggested that the Caribbean region may be part of a deep ocean basin in the process of being transformed into a continental area.

The Colombian Basin is known to contain a thick fill of turbidites from the Magdalena region, but the Venezuelan Basin contains a remarkably uniform sedimentary series, and an understanding of its geologic history should lead to an understanding of the nature of the Caribbean region as a whole. Ewing et al. (1968) have described sediment distribution in the Caribbean Sea, with particular emphasis on the nature of the sediments of the Venezuelan Basin as interpreted from profiler records of traverses through the area. Two prominent reflectors are recognized, termed $\mathrm{A}^{\prime \prime}$ and $\mathrm{B}^{\prime \prime} . \mathrm{A}^{\prime \prime}$ is usually the stronger, and $\mathrm{B}^{\prime \prime}$ is the lowest reflector but is considered to be far too smooth to be basement. The thicknesses of the strata between B" and $\mathrm{A}^{\prime \prime}$, and above $\mathrm{A}^{\prime \prime}$ in the central part of the Basin are remarkably uniform, each interval having been estimated from profiler records to be about 0.5 kilometer. $\mathrm{B}^{\prime \prime}$ and $\mathrm{A}^{\prime \prime}$ descend towards the sides of the 
Basin to disappear under turbidites spreading outward from South America and the Antilles. Ewing et al. (1968) have named the acoustically transparent strata above $\mathrm{A}^{\prime \prime}$ and the somewhat more opaque strata be-

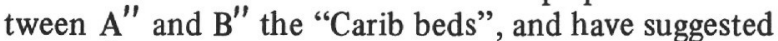
that $A^{\prime \prime}$ might coincide with the Mesozoic-Cenozoic boundary. They recognize three phases in the geologic history of the area: Phase I, prior to the deposition of the Carib beds; Phase II, during deposition of the Carib beds; and Phase III, after deposition of the Carib beds.

Site 29 was selected at a location where $\mathrm{A}^{\prime \prime}$ and $\mathrm{B}^{\prime \prime}$ are anomalously close to the sea floor, and where it was expected that the chance for penetrating to B" would be good. The character of the reflectors at the chosen site seems typical, and they can be traced into adjacent areas with the normal thickness. Multiple holes at this site enabled the entire section down to a depth of almost 250 meters to be sampled. The uppermost 130 meters corresponds to the interval above a discontinuous reflector present at this site, and consists of tan Globigerina-nannoplankton ooze grading down into "red clays" free of carbonate. The discontinuous reflector is interpreted as the contact between the red zeolitic clay and the underlying radiolarian ooze which extends down to 230 meters. Reflector $\mathrm{A}^{\prime \prime}$ is thought to correspond to the contact between the unconsolidated radiolarian ooze and the chert which lies below 230 meters depth. The upper part of the acoustically defined Carib beds corresponds to the radiolarian ooze, which is of Middle Eocene age (see Chapter 24, this volume), and possibly some of the overlying "red clay" The lower part of the Carib beds consists of chert, at least at the top of the sequence, as was already known from core samples taken from a fault scarp on the southeastern extension of the Beata Ridge into the Venezuelan Basin (Talwani et al., 1966; Edgar, in press). Work carried out by the Glomar Challenger has produced no data permitting a more detailed interpretation of Phase I of the history of the Caribbean region, but Phase II can be stated to have been a time of massive accumulation of siliceous sediments. Phase II also corresponds to the time of maximum connection of the Atlantic with the Pacific through the Panama-Costa Rica region (Schuchert, 1935; Eardley, 1951). North and South America were presumably connected during the Cretaceous, disconnected during the Eocene and early Miocene, and connected again since the Pliocene. During the Oligocene and later Miocene, the Central American region was probably a series of islands, restricting the mixing of Pacific and Atlantic waters. Phase III, which according to Ewing et al. (1968) "dates from the deformation that bent the Carib beds into their present configuration, and is characterized by gradual burial of the deeper parts of the floor by younger turbidites," may correspond to the OligoceneRecent. In any case, it now seems that if future drilling discovers siliceous oozes at other sites in the Caribbean, the Carib beds may be recognized as a formational unit composed of predominantly pelagic siliceous sediment. Although the age of this material is known to be Middle Eocene at Site 29, and Early Eocene on the fault scarp of the southeastern extension of the Beata Ridge (Talwani et al., 1966), the full extent of this deposit has not been determined.

\section{AVES RIDGE}

\section{Site 30}

This site, on the Aves Ridge, was chosen to provide a suitable reference section for calcareous plankton biostratigraphy, replacing Site 29 which had been found to lie mostly below the zone of calcium carbonate compensation during the pre-Pleistocene. The original intention was to core continuously through the Early Pleistocene, Pliocene, Miocene, and hopefully, older strata. By analogy with Hole 25 on the North Brazilian Ridge, it was expected that the Aves Swell would be mantled by planktonic foraminiferal-calcareous nannoplankton ooze, and that the section would have thicknesses typical for oceanic oozes with sedimentation rates of 0.5 to $1 \mathrm{~cm} / 10^{3}$ yrs.

Drilling revealed that the Pleistocene and Pliocene sediments are chiefly silts, probably derived from volcanic activity in the Grenadines to the east. The Pleistocene sedimentation rate was two orders of magnitude higher than would normally be expected, and the Pliocene sedimentation rate was about half that of the Pleistocene. The Miocene sediments were found to be chalk with an admixture of terrigenous material, but with a more normal pelagic sedimentation rate of about 0.25 $\mathrm{cm} / 10^{3}$ yrs. Large scale delivery of volcanically derived silts to the Aves Ridge in this region appears to have started during the Early Pliocene, and to have steadily increased during the later Pliocene and Pleistocene. Figure 3 is a schematic representation of transport, sorting and settling conditions for terrigenous sediments derived from volcanic sources in the Grenadines. The sediment is carried westward by the North Equatorial Current, and the diagram was prepared assuming an average velocity of $40 \mathrm{~cm} / \mathrm{sec}$. The diagram shows that the Grenada trough can be expected to have a thick accumulation of fine and very fine sand-sized material in addition to the turbidites which normally would be expected. The Aves Ridge should catch much of the silt, so that only the very fine silts and clays should be carried into the Venezuelan Basin.

The sedimentological peculiarities of the Aves Ridge hole are reflected in the grain size analyses. The Pleistocene sediments are mostly silty clays. The very small sand fraction is actually the tests of foraminifera and other microfossils, and is usually a few percentages. The sand fraction, chiefly the tests of planktonic foraminifera, in the Miocene chalks from the deeper part of 


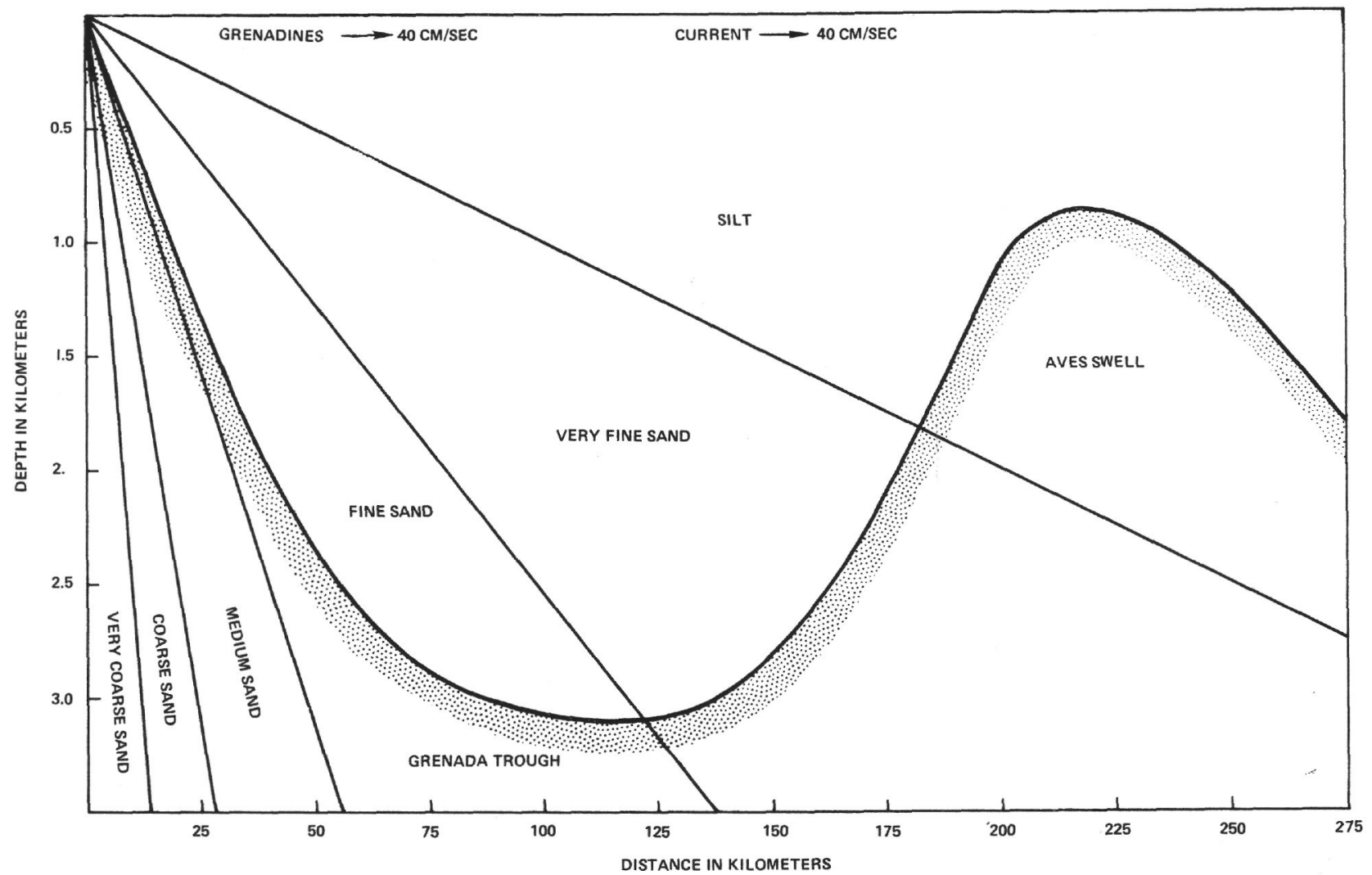

Figure 3. Schematic cross section from the Grenadines across the Aves Ridge, showing the settling regions for clastic particles introduced into the water near the Grenadines, assuming a current velocity to the west of 40 $\mathrm{cm} / \mathrm{sec}$. 
the hole is several tens of per cent, between one and two orders of magnitude greater than in the upper, higher sediments. This coincides generally with the much greater sedimentation rate for the younger sediments.

\section{BEATA RIDGE}

Site 31

This site was chosen at a location where it was thought that Horizon $\mathrm{A}^{\prime \prime}$ was absent, so that penetration to levels older than those sampled by Hole 29 might be achieved. Technical difficulties prevented sampling of strata older than Late Oligocene, but interesting new data on the later Tertiary history of the Beata Ridge have been revealed.

An excellent summary of the geology of the Beata Ridge has been presented by Fox et al. (1970). They indicate that the Ridge was produced by normal faulting during the early Tertiary, and that the crest of the Beata Ridge was close to sea level in the Eocene, citing the recovery of Eocene shallow water carbonate pebbles dredged from the steep western slope of the Ridge. They further indicate that by Late Oligocene time, the Ridge had subsided into deep water, remaining a site of pelagic sedimentation.

The deepest unit cored by the Glomar Challenger in Hole 31 is a somewhat indurated chalk of basal Miocene to Late Oligocene age. The planktonic foraminifera in the Late Oligocene chalk are somewhat corroded, indicating that deposition occurred in the upper part of the zone of calcium carbonate compensation. The basal Miocene chalk and Middle Miocene ooze show no signs of solution, and can be assumed to have been deposited above the zone of calcium carbonate compensation. The Pliocene samples show strongly corroded planktonic foraminifera and great enrichment of discoasters, suggesting that during this time deposition occurred in the lower part of the calcium carbonate compensation zone. The curve showing the fluctuation of the zone of calcium carbonate compensation in the Atlantic through the Late Cretaceous and Cenozoic (Figure 4) indicates that the compensation level rose during the Oligocene and Miocene and descended during the Pliocene and Pleistocene. The drilling at Site 29, to the east in the central part of the Venezuelan Basin, confirms this general scheme. At Site 31, however, the sediments least affected by calcium carbonate compensation are the Miocene chalk and ooze. This can only be interpreted as indicating that vertical motions of the Beata Ridge during the later Tertiary exceeded the fluctuations of compensation level. The observations are best explained by assuming that the Ridge had subsided to a depth in the lower part of the calcium carbonate compensation zone (probably about its present depth) by Late Oligocene time. During the Miocene the Ridge was uplifted somewhat, probably about 1000 meters or so.
Since the Miocene, the Beata Ridge has gradually subsided again to reach its present depth.

\section{SEDIMENTATION RATES (W. W. H.)}

The holes drilled on this leg have demonstrated extreme variations in sedimentation rates. Because few of the holes were continuously cored except for short intervals, calculations of sedimentation rates from one sequence of strata to the next requires a specific set of assumptions. The values are generally integrated over relatively long periods of time, and many minor fluctuations would be expected if more data were available. Absolute ages used to calculate sedimentation rates are estimated from the time scale of Berggren in Maxwell et al. (1970).

\section{Site 23}

The Lower Miocene Globorotalia kugleri Zone was encountered at a depth of about 120 meters. Estimating an age of about 25 million years for the middle or upper part of this zone, the calculated sedimentation rate is $4.8 \mathrm{~mm} / 10^{3}$ years for the "red clay" sequence in the upper part of the hole.

\section{Site 24}

The top of the turbidite sequence was at a depth of about 120 meters at Site 23, about 10 miles to the northwest. The prominent intermediate reflector at Site 24 was found to lie at a depth of about 0.15 to 0.2 second, the same depth as at Site 23, so that it can be assumed that this reflector, probably one of the turbidite sands, and the top of the turbidite sequence lies at about 100 to 120 meters at Site 24. Cores from 200 to 230 meters depth yielded turbidites similar to those at Site 23, also belonging to the Globorotalia kugleri Zone. By correlation between Holes 23 and 24, it can be assumed that the thickness of strata belonging to the Globorotalia kugleri Zone is in excess of 100 meters. The duration of this zone is not known with precision but is probably about 1 to 2 million years, so that a sedimentation rate of 50 to $100 \mathrm{~mm} / 10^{3}$ years may be calculated.

The age of the lower part of Hole 24 has been determined to be Campanian, according to radiolarian evidence. The Campanian-Lower Miocene sediments are about 265 meters thick, and probably represent a time span of about 50 million years. From these assumptions a sedimentation rate of $5.3 \mathrm{~mm} / 10^{3}$ years is calculated, close to that determined for the "red clay" sequence above the turbidites at Site 23.

\section{Site 25}

The sediments at Site 25 are planktonic foraminiferalcalcareous nannofossil oozes down to a depth of approximately 55 meters. The oldest of the oozes belong to the 


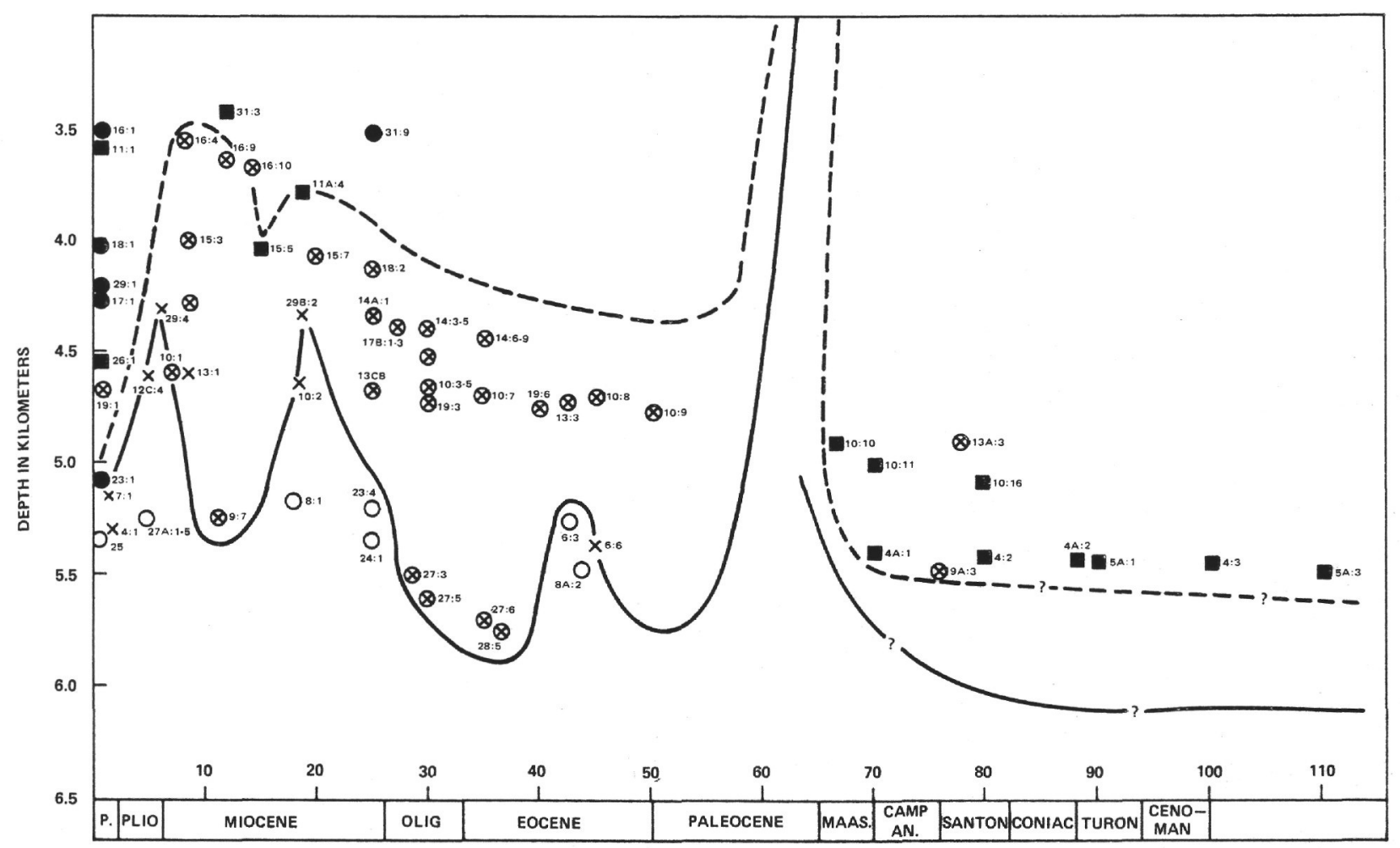

Figure 4. Schematic diagram of the vertical fluctuations in two important calcium carbonate compensation datum levels plotted against time: the upper curve (- $)$ indicates the lower limit of planktonic foraminiferal tests; the lower curve (-) indicates the lower limit of calcareous nannoplankton fossils. Time scale after Berggren in Maxwell et al. (1970). Solid circles (or squares): planktonic foraminiferal tests and calcareous nannofossils present; circles with $x$ in the center: calcareous nannoplankton fossils present; open circles: no calcareous plankton fossils present. Numbers beside symbols indicate DSDP Site number and core number from which data are derived. 
Globorotalia menardii Zone and have an estimated age of 11 million years. Sedimentation rate of the ooze would then be $5.0 \mathrm{~mm} / 10^{3}$ years, within the range of slower rates for calcareous ooze found on Leg 3 .

\section{Site 26}

At this site, the accumulation of over 600 meters of sediment occurred during the Middle and Late Pleistocene and Recent. An absolute age for the oldest sediments encountered is difficult to estimate, but 600,000 years is a reasonable figure, giving a sedimentation rate of $1000 \mathrm{~mm} / 10^{3}$ years.

\section{Site 27}

Coring was widely spaced in this hole, but the OligoceneMiocene boundary may be assumed to lie at about 300 meters depth. Estimating the age of the boundary at 26 million years, the rate of sedimentation for the sediments in the upper part of the hole would be 11.5 $\mathrm{mm} / 10^{3}$ years. This seems to be an unusually high value for non-turbidite sediment deposited mostly below the zone of calcium carbonate compensation.

The pre-Miocene-Late Eocene sediments in the lower part of Hole 27 are about 150 meters thick, and probably represent a time span of about 15 million years, indicating a rate of accumulation of $10 \mathrm{~mm} / 10^{3}$ years, strikingly similar to that for the post-Oligocene sequence.

\section{Site 28}

Because of uncertainties concerning the levels from which deeper samples were obtained, a sedimentation rate can be calculated only for the post Middle Eocene sequence in Hole 28, a sequence of beds about 180 meters thick. Estimating the age of the Discoaster tani nodifer Zone at 40 million years, the integrated rate of sediment accumulation for the upper part of the hole can be calculated to be $4.5 \mathrm{~mm} / 10^{3}$ years.

\section{Site 29}

The higher sediments in Hole 29 were alternatively deposited above and below the calcium carbonate compensation depth. The upper 125 meters of sediment belong to the Lower Miocene-Recent, a span of time interval of approximately 25 million years, giving a rate of accumulation of $5 \mathrm{~mm} / 10^{3}$ years.

The lower sequence of sediment in Hole 29, the radiolarian ooze, is of comparable thickness (about 120 meters), but was deposited during a much shorter period of time. The caiculation of sedimentation rates in this instance will depend strongly on the time interval estimated for the radiolarian ooze series. A span of 5 million years is probably a high estimate of the time involved, giving a rate of sedimentation of $24 \mathrm{~mm} / 10^{3}$ years.

\section{Site 30}

The Pleistocene sediments at Site 30 can be assumed to be at least 180 meters thick. Using a value of 1.8 million years for the base of the Pleistocene, the sedimentation rate is calculated to be at least $100 \mathrm{~mm} / 10^{3}$ years.

The Pliocene sediments are about 160 meters thick, and can be assumed to have accumulated in about 4 million years, giving a sedimentation rate of $40 \mathrm{~mm} / 10^{3}$ years.

The Late, Middle Miocene and late Early Miocene sediments in Hole 30 are about 60 meters thick. Using an estimate of 15 million years for the time span involved, the sedimentation rate is calculated to be $4 \mathrm{~mm} / 10^{3}$ years.

The strongly accelerating rate of sediment accumulation toward the top of this hole is correlated with the influx of silt from volcanic sources (see discussion of Site 30 elsewhere).

\section{Site 31}

Pleistocene sediments at this site are also unusually thick, comprising about 55 meters of strata. Again assuming a duration of 1.8 million years, the sedimentation rate is calculated as $30 \mathrm{~mm} / 10^{3}$ years.

Pliocene, Miocene, and Late Oligocene strata in Hole 31 are about 90 meters thick. Assuming a time span of 24 million years, the sedimentation rate is calculated to be about $8 \mathrm{~mm} / 10^{3}$ years.

\section{Summary}

Very low sediment accumulation rates such as were found for some "red clays" ( 0.2 to $3.0 \mathrm{~mm} / 10^{3}$ years for the Discovery clay) on Leg 3 (Maxwell et al., 1970) or cited as typical ( 0.7 to $2.0 \mathrm{~mm} / 10^{3}$ years) by Holmes (1965) were not found at any of the sites on Leg 4. Most sediments, unless obviously turbidites, have sedimentation rates of about 3 to $6 \mathrm{~mm} / 10^{3}$ years regardless of their content of calcium carbonate. The highest rate of accumulation was found in the Vema Fracture Zone, 1 meter $/ 10^{3}$ years, which is in the same order of magnitude as the rate of accumulation in the Mississippi delta.

\section{ON THE NATURE OF REFLECTING HORIZONS} (W. E. B. and R. D. G.)

\section{Introduction}

One of the more important geophysical tools developed for exploring the floor of the ocean is the continuous seismic profiler (Ewing and Tirey, 1961). Using a high energy acoustic source, commonly an electrical "arker" or a pneumatic "air gun", a signal is sent down, partially reflects off the bottom, but also penetrates below the 
sea floor and reflects off deeper sediment and rock layers beneath it. The profiler records the vertical cross section of the bottom and subbottom reflecting surfaces (interfaces caused by changes in acoustic impedance) along the ship's track. Seismic profiler records across many ocean basin areas commonly reveal one or more strongly reflective interfaces between the ocean bottom and "basement" (the deepest reflector below which no other reflectors appear).

Prior to the Deep Sea Drilling Project the smooth intermediate reflecting horizons of broad regional extent were believed to be fossil abyssal plains, while the normally rough basement was assumed to be crystalline rock, probably basalt. The cores obtained by the Deep Sea Drilling Project have aided greatly in the interpretation of the geophysical data and have also demonstrated that sweeping conclusions regarding the reflectors are hazardous.

\section{Intermediate Reflectors - Horizon A}

As a result of numerous seismic profiles, Ewing et al. (1966) and Windisch et al. (1968) have shown that in most parts of the North Atlantic, the sediments at some distance from the Mid-Atlantic Ridge have one, sometimes two, strong intermediate reflectors. The uppermost of these they called Horizon A, and suggested that it could be used for both stratigraphic correlation and structural interpretation. They did not claim that this was a single continuous bed, but that it seemed to be at about the same stratigraphic horizon everywhere. The results of Legs 1 through 3 of the Deep Sea Drilling Project confirmed their inferences. In both the western and eastern parts of the North Atlantic, Horizon A was shown to be a hard chert of Late Cretaceous to Eocene age; and the deeper and less prevalent Horizon Beta was also found to be chert of Cretaceous age. Evidently the Late Cretaceous-Eocene was a time when silica precipitation in the North Atlantic was greater than at any time since.

In the South Atlantic a reflecting horizon believed to be analagous to Horizon A has been traced over broad areas from the Rio Grande Rise to the southern Argentine Basin (Ewing et al., 1964). In the North Atlantic Horizon A is level regardless of sea floor topography, while in the Argentine Basin it is generally conformable to the topography.

Seismic reflection measurements along a transect from Recife, Brazil to Freetown, Sierra Leone (Leyden, Sheridan and Ewing, 1967) show a prominent intermediate reflector similar to Horizon A across the northwestern Brazil Basin, which is difficult to trace continuously near the Brazil slope owing to the presence of numerous seamounts. Unlike its counterpart in the eastern Atlantic Basin, this horizon in the western basin is not a seismic refractor.
Hayes and Ewing (1970) plot a broad area of the Demerara Abyssal Plain, underlain by a prominent intermediate reflector presumed to be comparable to Horizon A. However, it cannot be traced continuously to adjacent regions.

Drilling results from the Atlantic sites of Leg 4 point out that predictions on the nature of reflecting horizons in unsampled areas, based upon projections from sampled sites, can be misleading. Sites 23 and 24 had a strong reflector at about 137 meters (450 feet) that had been assumed to be Horizon A. Cores recovered at this depth show that the reflection is apparently due to a series of uncemented turbidites of Middle Miocene age. Site 24 bottomed in basalt, above which were sediments of Late Cretaceous age; no chert was encountered in the entire section.

Site 27 shows a very strong "A" reflector at about 69 meters (225 feet) and a less strong "Beta" reflector at about 236 to 244 meters ( 775 to 800 feet). The upper part of the section was cored continuously with good recovery and consisted of typical deep sea clays except for the interval at 67 to 70 meters ( 220 to 230 feet), which had two beds of sandy silt turbidites (Pleistocene or Pliocene). Evidently, the contrast in lithology between the clays and the turbidites can create sufficient change in acoustical impedance to show up as a reflector. Similarly, the lower reflector seems to be due to two thin turbidites of Miocene age.

Site 28, drilled on the Outer Ridge only 500 miles southeast of the well known Horizon A and Beta outcrop area (Ewing et al., 1966; Windisch et al., 1968), was expected to have a substantial intermediate chert reflecting horizon within the upper 200 meters (656 feet). This was not confirmed in the drilling, which penetrated to 404 meters (1325 feet). A problematic thin, hard layer or layers may have been encountered at and below 175 meters ( 574 feet), but the material was not sampled; unlike the true Horizon A chert, the reflecting layer did not stop the drilling operations.

It is apparent from these results that not all prominent intermediate reflecting horizons in the Atlantic are chert and that Eocene cherts are not ubiquitous. The above discussion should not be interpreted as negating the value of "Horizon A". It means that unless a strong reflector has been traced from a known area, or until it has been penetrated by the drill, it should not be presumed to be of any particular age or composition.

\section{Basement}

The depth below which the seismic profiler cannot penetrate is called "basement". In most areas of the ocean this geophysical basement is assumed to be basalt. On Leg 4 "basement" was penetrated at two sites, 24 and 27. At Site 24 it proved to be a basalt 
just below sediment of Campanian age. The shallow penetration of basalt at this site does not positively confirm that it is basement. At nearby Site 23 a thin basalt flow was penetrated at about 200 meters (656 feet), below which unconsolidated sediment of possible Upper Cretaceous age was penetrated. Comparison of the crystalline nature of the basalt samples at these two locations, however, suggests that the Site 24 sample has more the character of true basement basalt. At Site 27 the hole bottomed in a hard, clayey limestone, the cores of which show bedding which dips about $24^{\circ}$. The seismic basement at Site 27 (Figure 2) shows a rough topography with relief of about 0.5 second two-way travel time (about 450 meters (1476 feet) ). The correspondence of core depth with seismic depth and the sampling of steeply dipping limestone beds give support to the view that basement here consists of steeply folded limestone beds of Late Eocene age.

\section{CALCIUM CARBONATE COMPENSATION} (W. W. H.)

An extensive account of the problems of calcium carbonate compensation in the oceans and its relation to the accumulation of pelagic sediments has been presented by Hsu and Anderson in Maxwell et al. (1970, p. 445-453). They recognized and named five facies corresponding to different grades of calcium carbonate dissolution. The two end members of their series, the alytic and hololytic facies, represent sediments unaffected by dissolution and sediments from which virtually all calcium carbonate has been dissolved respectively. The three intermediate facies which they recognized were distinguished on the basis of the percentage of terrigenous matter and the percentage of (planktonic) foraminiferal tests present. The eolytic facies was defined as containing less than 10 per cent terrigenous matter and more than 10 per cent foraminiferal tests; the oligolytic facies was defined as containing more than 10 per cent but less than 30 per cent terrigenous matter and less than 10 per cent foraminiferal tests; the mesolytic facies contains more than 30 but less than 70 per cent terrigenous matter, and less than 3 per cent foraminiferal tests. The end members of this series are easily recognized, but the intermediate facies are more difficult, especially in areas proximal to the continents where the amount of terrigenous matter is largely a function of sediment provenance, not calcium carbonate dissolution.

As was noted on Leg 3 and in a number of previous publications, pelagic foraminifera are more readily dissolved than calcareous nannofossils, but within both groups there is differential solution so that some species are removed at levels considerably higher than those at which the most resistant forms are dissolved.
Figure 4 represents the data available from a survey of Leg 4 and the previously published Atlantic legs concerning the fluctuation in the depth of two important calcium carbonate compensation surfaces through time. The upper surface is the lower limit of occurrence of the tests of pelagic foraminifera, the lower surface the lower limit of the occurrence of calcareous nannofossils. "X" indicates a datum point which lies on the lower compensation curve, that is, the transition from nannofossil bearing clay to barren "red" clay occurs within a single core barrel and can be accurately dated.

From these data, it is evident that considerable fluctuations in these two levels recognized have taken place during the Cenozoic and Cretaceous. Hsu and Anderson in Maxwell et al. (1970) interpreted their data as indicating that the calcium carbonate compensation level remained at a constant depth in the oceans while the ocean floor moved up and down. The fluctuations suggested by Figure 1 would require a complex motion of the ocean floor over broad areas. These are more easily explained by assuming that the only vertical motion of points on the ocean floor has been downward as they moved away from the crest of the Mid-Atlantic Ridge, but that the zone of calcium carbonate compensation has fluctuated through considerable distances in the water. During the latter Tertiary, this fluctuation would be in the order of 1 kilometer. An extreme fluctuation is postulated for the end of the Cretaceous-early Paleocene, at which time the two compensation levels indicated here are thought to have risen well into the photic zone (Tappan, 1968; Worsley, 1970).

\section{REFERENCES}

Ball, M. and Harrison, C., 1970. Crustal plates in the Central Atlantic. Science. 167, 1128.

Beckmann, J. P., 1954. Die Foraminiferen der Oceanic Formation (Eocaen-Oligocaen) von Barbados, Kl. Antillen. Eclogae Geol. Helv. 46, 301.

Blow, W. H., 1969. Late Middle Eocene to Recent planktonic foraminiferal biostratigraphy. Proc. First Intern. Conf. Planktonic Microfossils. Geneva, 1967. Leiden (E. J. Brill) 1, 199.

Bullard, E., Everett, J. E. and Smith, A. G., 1965. The fit of the continents around the Atlantic, a symposium on continental drift. Phil. Trans. Roy. Soc. London, A. 258, 41.

de Cizancourt, M., 1948. Nummulites de l'ile de la Barbade (Petites Antilles). Mem. Soc. Geol. France, N. S. 57, 3.

Eardley, A. J., 1951. Structural Geology of North America. New York (Harper and Bros.) 624 pp.

Edgar, T., 1968. Seismic Refraction and Reflection in the Caribbean Sea. Ph.D. thesis, Columbia University, New York.

Ewing, J., Talwani, M. and Ewing, M., 1968. Sediment Distribution in the Caribbean Sea. Fourth Caribbean Geol. Conf. 1965, p. 317. 
Ewing, J. and Tirey, G., 1961. Seismic profiler. J. Geophys. Res. 66, 2917.

Ewing, J. I., Officer, C. B., Johnson, H. R. and Edwards, R. S., 1957. Geophysical investigations in the eastern Caribbean: Trinidad Shelf, Tobago Trough, Barbados Ridge, Atlantic Ocean. Bull. Geol. Soc. Am. 68, 897.

Ewing, J. I., Windisch, C. and Ewing, M. (in press). Correlation of Horizon A with JOIDES bore hole results. J. Geophys. Res. 1970.

Ewing, J. I., Worzel, J. L., Ewing, M. and Windisch, C., 1966. Ages of Horizon A and the oldest Atlantic sediments. Science. 154, 1125-1132.

Ewing, M., Le Pichon, X. and Ewing, J. I., 1966. Crustal structure of the mid ocean ridges, 4 . Sediment distribution in the South Atlantic Ocean and the Cenozoic history of the Mid-Atlantic Ridge. $J$. Geophys. Res. 71, 1611.

Ewing, M., Ludwig, W. J. and Ewing, J. I., 1964. Sediment distribution in the oceans: The Argentine Basin. J. Geophys. Res. 69, 2003.

Ewing, M., Worzel, J. L., Beall, A. O., Berggren, W. A., Bukry, D. Durk, C. A., Fischer, A. G. and Pessagno, E. A., Jr., 1969. Initial Reports of the Deep Sea Drilling Project, Volume I. Washington (U. S. Government Printing Office) $672 \mathrm{pp}$.

Fischer, A. G., Heezen, B. C., Boyce, R. E., Bukry, D., Douglas, R. G., Garrison, R. E., Kling, S. A., Krasheninnikov, V., Lisitzin, A. P. and Pimm, A. C., (in press). Geological history of the western North Pacific. Science. (1970).

Fox, P. J., Pitman, W. and Shephard, F., 1969. Crustal plates in the central Atlantic: Evidence for at least two poles of rotation. Science. $165,487$.

Hayes, D. E. and Ewing, M. (in press). The North Brazilian continental margin. Bull. Am. Assoc. Petrol. Geol. (1970).

Hersey, J. B., 1966. Marine geophysical investigations in the West Indies. Geol. Surv. Canada, Paper 66-15, 151.

Holmes, A., 1965. Principles of Physical Geology. New York (The Ronald Press Co.) (2nd. Ed.) 1288 pp.

Le Pichon, X., 1968. Sea floor spreading and continental drift. J. Geophys. Res. 73, 3661.
Leyden, R., Sheridan, R. and Ewing, M. (in press). A seismic refraction section across the equatorial Atlantic. Symp. Continental Drift, Montevideo, 1967.

Maxwell, A. E., Von Herzen, R. P., Andrews, J. E., Boyce, R. E., Milow, E. D., Hsu, K. J., Percival, S. T. and Saito, T., 1970. Initial Reports of the Deep Sea Drilling Project, Volume III. Washington (U. S. Government Printing Office) 806 pp.

Morgan, W. J., 1968. Rises, trenches, great faults, and crustal blocks. J. Geophys. Res. 73, 1959.

Officer, C. B., Ewing, J. I., Hennion, J. F., Harkrider, D. G. and Miller, D. E., 1959. Geophysical investigations in the eastern Caribbean: Summary of 1955 and 1956 cruises. Phys. Chem. Earth. 3, 17.

Saunders, J. B. and Cordey, W. G., 1968. The biostratigraphy of the Oceanic Formation in the Bath Cliff Section, Barbados. Trans. 4th Caribbean Geol. Conf. 179.

Schuchert, C., 1935. Historical Geology of the Antillean-Caribbean Region. New York and London (John Wiley and Sons, Inc.), $811 \mathrm{pp}$.

Senn, A., 1940. Paleogene of Barbados and its bearing on the history and structure of Antillean-Caribbean region. Bull. Am. Assoc. Petrol. Geol. 24, 1548.

1948. Die Geologie der Insel Barbados B. W. I. (Kl. Antillen) und die Morphogenese der umliegenden marinen Grossformen. Eclogae Geol. Helv. 40, 199.

Talwani, M., Ewing, J. I., Ewing, M. and Saito, T., 1966. Geological and geophysical studies of the Caribbean submarine escarpments (Abstract). Trans. Geol. Soc. Am., Annual Meeting. 217.

Tappan, H., 1968. Primary production, isotopes, extinctions and the atmosphere. Paleogeography, Paleoclimatology, Paleoecology. 4, 187.

Valencio, D. A. and Vilas, J. F., 1970. Palaeomagnetism of some Middle Jurassic lavas from South-east Argentina. Nature. 225, 262.

van Andel, T. H., Corliss, J. B. and Bowen, V. T., 1967. The intersection between the Mid-Atlantic Ridge and the Vema Fracture Zone in the North Atlantic. $J$. Marine Res. 25, 343.

Windisch, C., Leyden, R., Worzel, J. L., Saito, T. and Ewing, J., 1968. Investigation of Horizon Beta. Science. 162, 1473. 